\title{
動物ゲノムの構造と複製に関する分子細胞遺伝学的研究
}

\author{
（1996 年度農芸化学奨励賞受賞）
}

\author{
奥 村 克 純 \\ (三重大学生物資源学部)
}

Key words: fluorescence in situ hybridization (FISH) : genome structure; DNA replication : mammalian genome; genomic imprinting

はじめに

現在，種々の生物について世界規模でゲノム計画が 進行し，数多くの遺伝子やDNA 配列が同定され明らか にされつつある．生命活動を維持するこれらの遺伝子 (群)がいかにうまく，しかも決まった時期にその機能 を発揮しているかを知り，我々がこれらをいかに効率 よく発現させて利用するか，さらに，細胞や動物個体 のもつ機能を遺伝子レべルでいかに都合上く改良する かといった課題に取り組むためには，標的遺伝子(群) が存在するゲノムの構造やゲノムとこれをとりまく種々 の因子との相互作用，さらにそ机らが遗伝子やゲノム の機能発現のために細胞核内でいかにダイナミックな 構造変化を起こしているかというゲノムの動的挙動に 関する知見が必要不可欠である，細胞核内の一コピー の各遺伝子を多色で検出できる技術として開発・改良 されてきた蛍光 in situ hybridization (FISH) 法は, このような要望に応え得る可能性をもつ一つの技術で ある、筆者らは，FISH 法を利用して社会的にも最も重 要視され，研究の進展が著しいヒト・ゲノムを哺乳類 ゲノムの代表例として研究を進めている。この複雑で はあるが極めて精妙に制御を受けている動物細胞ゲ， ムの, 様々な局面での構造やその変化を視覚的に描き 出し, ゲノムの構造と DNA 複製や遺伝子発現, 細胞 内で起こっている様々な現象や個体レベルでの表現型 とゲノム構造との関連性を明らかにすることを目標と

+ Molecular Cytogenetics of the Genome Organization and the DNA Replication in Animal Cells

Katsuzumi OKUMURA (Laboratory of Biological Chemistry. Faculty of Bioresources, Mie University)
している.ここでは，筆者らがここ数年間行ってきた 研究を中心に FISHによる動物ゲノムの解析について 最新の情報を抢りまぜて紹介する。

\section{FISH 法によるゲノム構造の解析}

DNA を検出する FISH 法は，その開発以来，遺伝子 やゲノム断片のマッピングを中心にヒト・ゲノム計画 を支える基本的技術としてその有効性をいかんなく発 揮してきだ(1).ゲノム解析に扔ける FISHに対するニー ズがその技術開発を促し，検出し得る最小サイズとし て数百塩基対 $(\mathrm{bp})$, 解像度としては数千 $(\mathrm{kb})$ から数 百万塩基対 $(\mathrm{Mb})$ におよぶ笧囲で解析できる系，さら に，種々の色で各 DNA を識別するマルチカラーFISH が確立している. FISH 法は，その開発当初から予想さ れたように，疾患の診断や，種々の生物学的研究への 応用が可能となり，その技術と応用性については，成 書(2)等を参照されたい.

FISH 法とは，まず検出したい遺伝子DNA を，例え ばビオチンで標識する，これを一本鎖にして，スライ ドガラスに固定した染色体 DNA（予め一本鎖にする） に in situでハイブリダイゼーションさせる.これをさ らに蛍光標識アビジンや標識抗体と結合させ，顕微鏡 下に一コピーの遺伝子を点状のシグナルとして検出す るという方法で, DNA の標識法と蛍光色素の組み合わ せを変えることにより，多色で視覚化することができ る方法である。

FISH 法のヒト・ゲノム計画への貢献は，もちろん， 遺伝子・ゲノムの染色体マッピングであり，これにつ いても様々な技術開発・改良がなされてきた。なかで

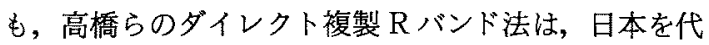
表する技術開発の一例である(3). 以来, ゲノムプロジェ クトの急進展と共に FISH においても解像度における 改良もなされてきた。伸展染色体(4)，DNA ファイバー など(5)，標本作製法の改良も進み，現在のところ目的に 
応じて数 $\mathrm{kb}$ から数 $\mathrm{Mb}$ の範囲での解析が可能である. 筆者らも，これらの技術改良を進める一方，FISH 法の 効率化と応用性に特に有効な高感度冷却 CCD カメラシ ステムを導入して FISH データをデジタルイメージ化 し，研究を進めてきた.まず，ゲノム解析の例として， ヒト 16 番染色体上に散在する DNA クローンのマッピ

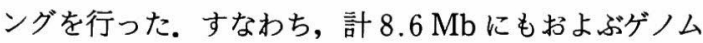
領域について DNA クローンの整列化と染色体上の位置 決定を行うことにより，ヒト 16 番染色体ゲノム構造解 析の基盤となるデー夕を提示した ${ }^{(6)}$. また, この過程で, 急性非リンパ球性白血病 (ANLL) 細胞に頻発する染 色体転座領域付近に 16 番染色体特異的反復配列が存 在することを発見した ${ }^{(7)}$. さらに，機能的に関連する数 多くの遺伝子, すなわち, DNA 複製関連遺伝子群やプ ロテアソームのサブユニット群等のゲノム上の存在位 置を決定した ${ }^{(8-11)}$. この結果，なかにはカゼイン遺伝 子のようにゲノム上でクラスターを形成するものもあ るが(12) (図 1)，機能発現時には協調して役割を果たす 遺伝子が，全く異なる染色体に存在して発現調節を受 けることが明らで，これらがいかに制御を受けている かという問題も今後の研究課題として大変興味樑い.

この他，Mbにもおよぶゲノム DNA をクローン化で きる酵母人工染色体 (YAC) の作製時に問題となるキ メラクローンの検出や(13)，マウス由来の遺伝子の遺伝 子座の決定, transgene の検出, 遺伝子の増幅様式に 関する研究にも FISH 法を活用した(14).このようにヒ

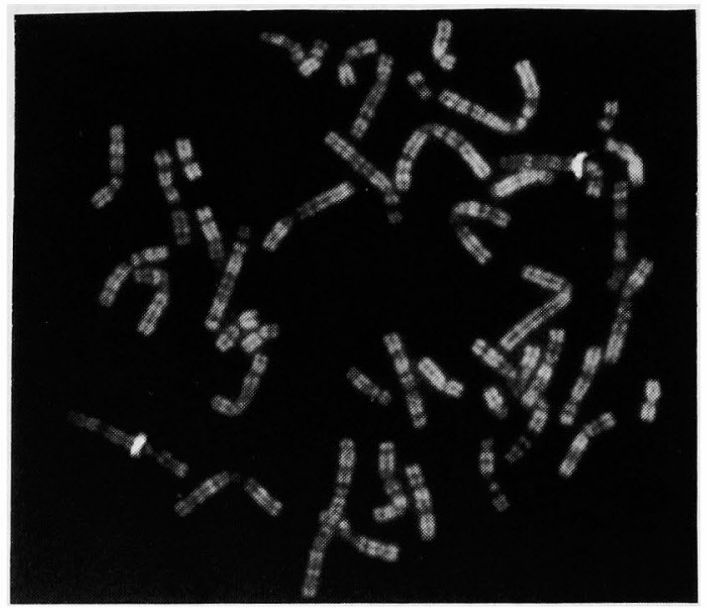

図 1 FISH によるヒト・カゼイン遺伝子のマッピング $\beta-, \mathcal{x}$-Casein 遺伝子を含む約 $1.5 \mathrm{Mb}$ の YC クロ ーンを FISH で検出し，4 q 21.1 にマップした.
ト・ゲノム解析を中心に進展した FISH 法はマウスや 他の家畜，ニワトリ，イネを代表とする植物，酵母等 のゲノム解析にも活用されている(15,16). FISH 法はいわ ゆるゲノム計画の発展に貢献してきたが, 一方で細胞 核内のゲノムのダイナミックな挙動を描き出し, 種々 の現象を視覚的に証明する可能性をもつ有力なツール でもある(17). 以下に応用例を述べる。

2. FISH 法によるDNA 複製タイミングの判定法 動物細胞のゲノム DNA の複製は細胞周期の S 期に 起こり，しかも個々の DNA セグメントは S 期の中で 決まった複製時期（複製夕イミング）をもつことが知 られている(18). DNA 複製タイミングの決定には，従来， セルソーターによる S 期の細胞分画，密度勾配超遠心， サザンブロッティング，オートラジオグラフィー等を 駆使し, 多くの細胞を必要とする大変煩雑な方法が用 いられていたが，我々はFISH 法による単純な方法を 提示した(19). すなわち，調べたい DNA 断片を蛍光検 出できるように標識して核標本に対して FISH を行う と, 二倍体細胞ではそのゲノム領域が複製していない 場合には，二つのシングルドット（SS）既に複製を終 えている場合には二つのダブルドット (DD) として検 出される．表 1 に示すように，細胞周期の進行に伴い, 核内の FISH シグナルはシングレットからダブレット に変化する．この割合を比較すれば，個々のゲノム断 片の相対的な複製タイミングを知ることができる. DNA 複製タイミングに大きな差がある DNA 間で比較する場 合は, その判定は容易であるが，細胞周期の非常に遅 い細胞や，複製タイミングの似ている DNA 閔で比較す る場合には，単純ではない。一つの方法として，細胞 培養時, 固定直前に 10 分ほどブロモデオキシウリジン (BrdU) を添加して取り込ませ，FISH の検出ステップ

表 1 細胞周期の進行に伴う核内 FISH シグナルの変化

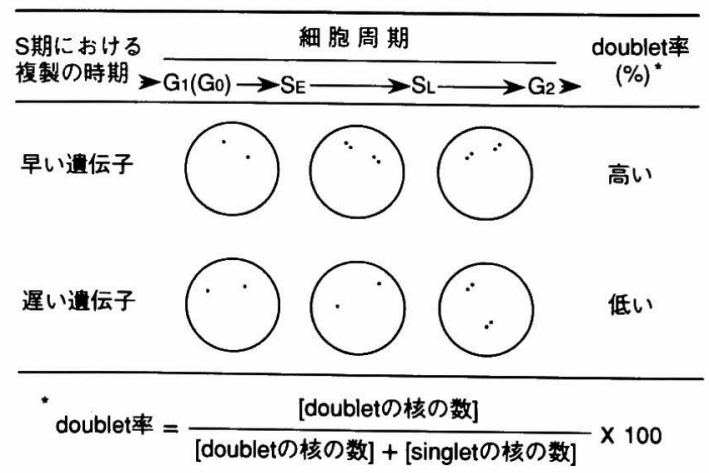


で，例えばローダミン標識した抗 BrdU 抗体で $\mathrm{S}$ 期に ある細胞のみを選択し，これについて SS, DD を判定 すれば，より正確なデータが得られる。

遺伝子発現と複製タイミングについては，一般にあ る遺伝子を発現している細胞では，その遺伝子は早い 複製タイミングをもち，逆に眠っていると遅く複製す るといわれている．例えば $\beta$-globin 遺伝子は K 562 細 胞では早く, HL 60 細胞では遅く複製する(18). 一方で, マクロなレベルではあるが, R バンド領域は遺伝子密 度が高く, 複製も $\mathrm{S}$ 期の前半に起こり, $\mathrm{G}$ バンド領域 は, $\mathrm{S}$ 期の後半に複製することがわかっており, 個々の 遺伝子の複製タイミングが細胞の種類によって変化す ることがあるので, 遺伝子発現と複製タイミングが常 に相関するとは考えにくい. 構造的要因を含め, 種々 の因子が影響を与えるのであろう.

遺伝子の複製タイミングの持つ意味，およびこれを 規定する要因について一定の見解を示すには現在のと ころあまりにも情報量が少ない. 以下に,これらに対 する解答を得るための初歩的なステップとして, DNA 複製タイミングとゲノムの構成, 遺伝子発現, クロマ チンの修飾などの関連性について検討した結果を, 他 のグループの結果をおりまぜて紹介する.

3. 囊胞性線維症 (cystic fibrosis；CF) 原因遺伝 子領域の複製タイミング

上述の FISH によるDNA 複製タイミングの判定法 をまず, $\mathrm{CF}$ 原因遺伝子 $(C F T R)$ 領域の複製タイムゾ ーンを描き出すために利用した ${ }^{(19)} . \mathrm{CF}$ 原因遺伝子領域 はヒト 7 番染色体長腕 $(7 \mathrm{q} 31)$ に存在する. 従来法に よる解析から，CFTR 遺伝子の上流に複製タイミング

表 2 CF 原因遺伝子領域の各細胞における複製タイミング

\begin{tabular}{|c|c|c|c|c|}
\hline \multirow{2}{*}{$\underset{\text { クローン }}{\text { DNA }}$} & \multicolumn{4}{|c|}{ doublet 率(\%), 複製タイミング } \\
\hline & K 562 & Manca & Caco 2 & \\
\hline cM 58 & $47 \mathrm{SE} / \mathrm{M}$ & $46 \mathrm{SE} / \mathrm{M}$ & 467 & \\
\hline cW 7-26 & 207 & 167 & 44 & $\mathrm{SE} / \mathrm{M}$ \\
\hline cNH 24 & 27 & 14 & $47-$ & \\
\hline cJ 21 & 26 & 13 & $66-$ & \\
\hline $\mathrm{cW} 44$ & 21 & 13 & 62 & $\mathrm{SE}$ \\
\hline$\lambda \mathrm{TE} 26 / 27$ & 18 & 13 & $67-$ & \\
\hline$\lambda \mathrm{W} \mathrm{30/46}$ & nd & nd & $25 \neg c$ & \\
\hline$\lambda \mathrm{W} 31$ & 19 & $9-$ & $31-$ & \\
\hline$\beta$-globin & $61 \mathrm{SE}$ & $4 \mathrm{SL}$ & $15 \mathrm{SL}$ & \\
\hline$P Y G M$ & $68 \mathrm{SE}$ & $77 \mathrm{SE}$ & $64 \mathrm{SE}$ & \\
\hline
\end{tabular}

の変化する領域が存在することが推定されたが, 正確 な変化領域を決定するには至らなかった。 そこで, CFTR の近傍領域の DNA クローンを用いて, FISH 法
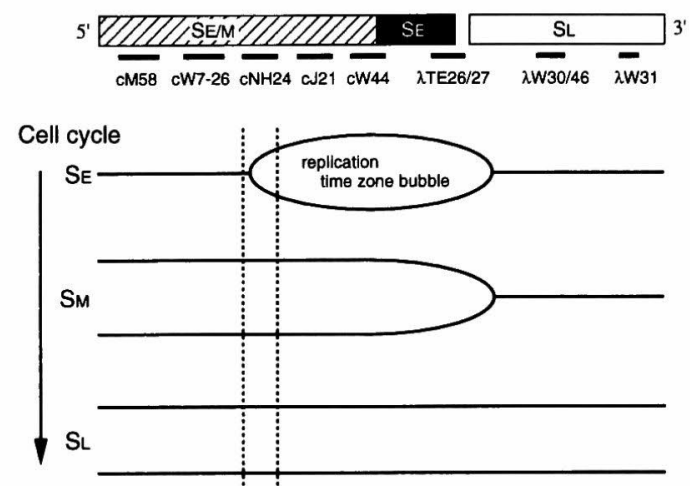

図 2 CFTR 遺伝子発現細胞 (Caco 2) でのこの遺伝子領域 の複製の進行過程

(上図）CFTR 遺伝子ゲノム領域の複製タイムゾーン のモデルおよびマップ(黒い部分はCFTR 遺伝子). $\mathrm{SE} / \mathrm{M}: \mathrm{S}$ 期前中期, $\mathrm{SE}: \mathrm{S}$ 期初期, $\mathrm{SL}: \mathrm{S}$ 期後期. ゲノム領域が複製タイミングに応じたゾーンとなって いることを示す.（下図）S 期における複製の順序. 破線ではさんだ部分で複製タイミングがスイッチする. $\mathrm{SE}$ に一時的に “replication time zone bubble” が 形成される。

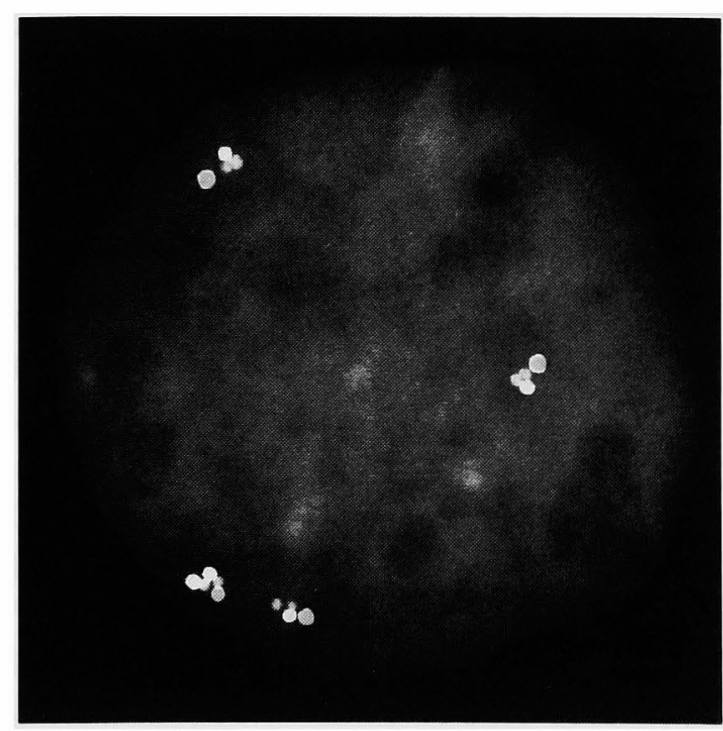

図 3 マルチカラーFISH による CF 原因遺伝子領域の複製 順序の描出

CFTR 遺伝子を発現するCaco 2 細胞核に対し,

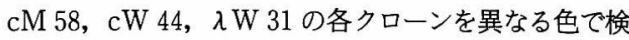
出した. CFTR 遺伝子がこの領域内で先に複製する ことを描出し, 図 2 のモデルを検証した. 
による複製タイミングの解析を行った，表 2 に示した 結果から，CFTR 遺伝子を発現しない細胞（K 562， Manca)では，この遺伝子の上流域が先に複製するが, これを発現する Caco 2 細胞では，CFTR 遺伝子を含む 領域がまず複製し, 続いて上流域, さらに下流域の順 に複製することがわかった．また，CFTR 遺伝子の上 流域の複製タイミングの変化領域をマップすることも できた，すなわち，図2に示すように，CFTR 遺伝子 自体は約 $500 \mathrm{~kb}$ にわたる複製タイムゾーンにあり，こ の遺伝子がアクティブな細胞では早く複製するが，眠 っている細胞では逆に遅く複製し，発現細胞では一時 的に, “replication time zone bubble" が形成される. この両側のゾーンに存在する DNA クローンを併用する ことで，マルチカラーFISH 法により，これを描き出 すことに成功した (図 3)。このタイムゾーンは複製に おける染色体構造の基本単位を示していると考えられ る.

\section{4. ゲノムの構造と DNA 複製タイミングの解析}

哺乳類のゲノムは $\mathrm{G}+\mathrm{C}$ 含量に基づく“isochore”と いうモザイク構造から成り立っていることが示されて きた ${ }^{(20,21)}$ 。これらのモザイク構造は染色体の G，R と いうバンド構造と密接な関連があり，BrdUでラベルし た細胞から調製した中期染色体にみられる一連のDNA 複製バンドパターンとも関連している。すなわち，七 ト・ゲノムの $\mathrm{R}$ バンドの大部分は $\mathrm{G}+\mathrm{C}$ rich であり， これらの領域は細胞分裂周期における S 期の前半に複

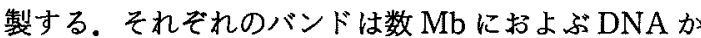
らなり，おそらくは統括的に制御を受けて複製するレ プリコン群で構成されていると考えられる，免疫応答 系の遺伝子が多数存在しているヒト主要組織適合抗原 複合体遺伝子群 $(\mathrm{MHC})$ 領域は, 約 $4 \mathrm{Mb}$ の長さをも ち， $\mathrm{R}, \mathrm{G}$ バンドの複合ゾーンよりなっている．また， $\mathrm{G}+\mathrm{C}$ 含量に基づくゲノムモザイク構造の境界が，MHC ClassII と ClassIII の境界領域に存在することを国立遺 伝学研究所の池村らが見出している(22). DNA 複製とゲ ノムの構造の関係に関する知見を得るためにこの領 域のうち入手し得る $2 \mathrm{Mb}$ 以上にわたる領域に存在する DNA クローンを用いて，上述の FISH 法によるDNA 複製タイミング決定法により解析した. DNA プローブ 間のより詳細な複製時期の比較をするために, DNAク ローンを 2 個ずつ併用し，異なる色で検出するマルチ カラーFISH で精密な解析を行った，HL60 細胞につ

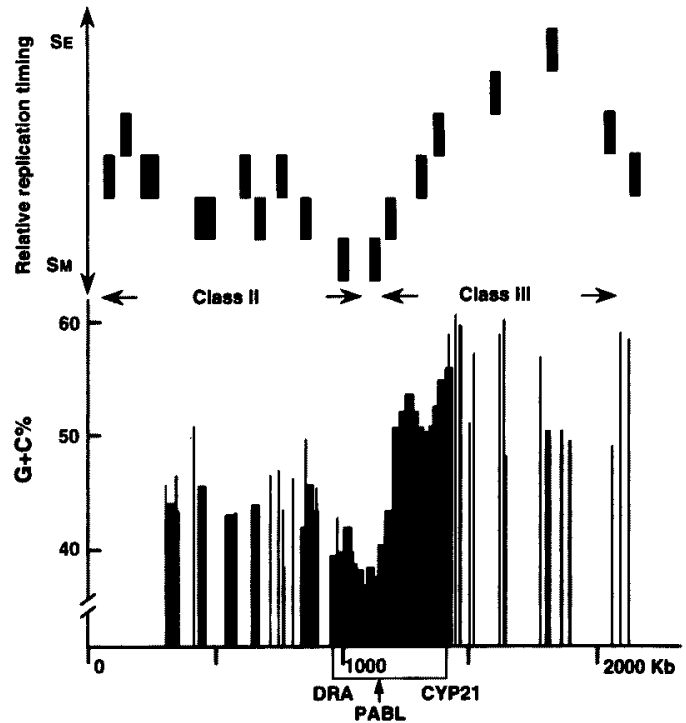

図 4 ヒト $\mathrm{MHC}$ 領域のゲノムの $\mathrm{G}+\mathrm{C} \%$ 組成と複製タイミ ング

$\mathrm{SE}_{\mathrm{E}}$ : $\mathrm{S}$ 期初期, $\mathrm{S}_{\mathrm{M}}$ ：S 期中期. 下部の $\mathrm{G}+\mathrm{C} \%$ 組成 は文献 22 の図を一部変更して使用した。

いて，約 $2 \mathrm{Mb}$ にわたる MHC 領域の相対的な DNA 複 製のタイミングを比較し，池村らによって示されたゲ ノム上のこの領域の $\mathrm{G}+\mathrm{C} \%$ の構成と共に図 4 に示した。 その結果，調べた領域内でDNA 複製のタイミングが最 も遅い領域が，ClassII と ClassIII の境界領域に見出さ れた．図から明らかなようにゲノムの $\mathrm{G}+\mathrm{C} \%$ の変化の パターンと DNA 複製タイミングの順序のパターンが密 接に関連していることも明らかとなった。これは，ゲ ノムの G+C\%組成と DNA 複製タイミングとの関連が ミクロなレベルで示された最初の例である。また,こ れらの結果はClassII と ClassIII の境界領域はDNA 複 製過程におりる replicon cluster $^{(23)}$ の境界に相当する 可能性を示唆している(24).

さらに, 遺伝子発現の複製タイミングへの影響を見 るために ClassII の遺伝子群を発現するリンパ芽球細胞 について同様に MHC 領域の複製タイミングを解析し た結果, 複製タイミングの最も遅い領域が, ClassII と ClassIII の境界領域に存在する点は変わらないものの， ClassII の遺伝子群を発現しない HL 60 細胞と比較し て, ClassII 領域の全体的な複製タイミングが相対的に 早くなっていた．両者の細胞で発現していないがん壊 死因子遺伝子 $(T N F)$ 領域が調べた領域て最も早く複 製することをも考慮に入れると，DNA 複製のタイミン 
グは，少なくともゲノムの構成，遺伝子発現の両者の 影響を受けるが，その影響の受け方は，ゲノム領域に よって異なることを意味している.

\section{5. インプリント遺伝子領域の複製タイミングと核 内ゲノム構造}

ゲノムインプリンティングは, 特定の遺伝子(領域) が父母の何れに由来するかを記憶する現象であり，父 方, 母方由来の一対のアレル(対立遺伝子)のうち, 特 定の一方だけが発現する。これは，配偶子形成過程に 何らかの刷り込み機構が働くためで，その機構の一部 としてDNAのメチル化がよく研究されている．最近の 研究からインプリンティングを受ける遺伝子(以下，イ ンプリント遺厷子) がクラスターを形成していること が明らかになり, 染色体ドメインレベルの研究が展開 されつつある、一方で, インプリント遺伝子が存在す る領域は，DNA 複製タイミングにおいても，アレル間 で異なる. 文献（25）でも紹介したように，これまで に FISH で調べられたインプリント遺伝子領域は，す ベてアレル間で非同調的複製を示す。表 3 にヒ卜 11 番 染色体短腕に存在するインスリン様成長因子 II 型遺伝 子(IGF2)のグノムクローンの複製タイミングを FISH で検討した結果を同調的に複製する遺伝子とともに示 した．これらの結果は，BrdUの取り込みを検出して 期の核のみを選択したものであるが，表から明らかな ように，アレル間で異なる複製タイミングを示す $\mathrm{SD}$ パ ターンが多く，一方のアレル(父方)が， S 期前半に複 製するのに対し，もう一方のアレル（母方）が S 期後 半に複製する。他の同調的に複製するクローンは SD パ ターンは高々 $10 \%$ 以下（クローンによっては $15 \%$ 前後 となる場合がある）と明らかに低い，さらに，マウス Igf2 についてはアレル特異的なマーカーを併用した FISH により，発現している父方のアレルが複製においても 早く，非発現の母方のアレルは遅く複製することが示 されている(26).

表 3 インプリント遺伝子のアレル間での非同調的複製

\begin{tabular}{|c|c|c|c|}
\hline \multirow{2}{*}{ DNA } & \multicolumn{3}{|c|}{ S 期核に扔ける FISH シグナルのパターン (\%) } \\
\hline & SS & $\mathrm{SD}$ & $\mathrm{DD}$ \\
\hline$E G F 2$ & 28.3 & 53.0 & 18.7 \\
\hline$T N F$ & 20.2 & 6.7 & 73.1 \\
\hline KS43 & 46.3 & 8.1 & 45.6 \\
\hline RFC5 & 36.2 & 6.0 & 57.8 \\
\hline
\end{tabular}

それでは,インプリント遺伝子の発現とそのゲノム の複製タイミングは相関するのであろうか？ 答えは， ノーである.Igf 2 の約 $90 \mathrm{~kb}$ テロア側に存在する $H 19$ は，母方が発現するのに，複製タイミングについ てはIgf2 と同様に父方が早く複製する(26).さらに， Igf2 ゲノムの周辺領域は発現においては，インプリン ティングを受ける，受けない点で細かい調節を受けて いるが，DNA 複製タイミングについてはもうすこし広 い範围で同じ一方のアレルが複製するようである。一 方，ヒ卜 small nuclear ribonucleoprotein-associated polypeptide N (SNRPN) 領域のように早い複製夕イ ミングが父方から母方へスイッチするゲノム領域もあ る(27).このようにインプリント遺伝子が存在するゲ， ム領域は，少なくともMb以上にわたってアレル間で 非同調的な複製制御を受け，遺伝子発現と同様に複雑 な調節を受け，ゲノム上で複製タイミング制御ドメイ ンともいうべき領域を形成していると考えられる。

マウスに打けるインスリン様成長因子 II 型/マンノー ス 6 リン酸受容体遺伝子 $(\operatorname{Ig} f 2 / M p r)$ 領域の複製夕 イミングも同様である。この遺伝子領域はマウス 17 番 染色体に存在し，アレル間で広大な領域にわたって非 同調的複製を示すことが明らかにされている(23,26)．筆 者らは, パラホルムアルデヒドを用いて立体構造を保 持するように固定した核について FISH を行い，紐胞 周期に依存した核内ゲノムの配置や伸縮を解析してお り，このゲノム領域がアレル間でどのような伸縮の相 違を示すかを検討した，立体的に固定した線維芽細胞 核に対してこの領域に散在するDNAをプローブとして FISH を行ったところ，個々の核内には父方，母方由来 の一対のそれぞれの FISH シグナルが一団となって観 察されるが，一方の FISH シグナルはコンパクトにま とまっているのに対し，もう一方のシグナルは広い範 囲に伸展している場合が多く観祭された。一方のアレ ルが複製し，もう一方が複製していないときには明ら かにアレル間の相違が観察されると予想されるが，両 者が複製していないときにゲノムの伸縮に違いがある のだろうか。この答えを得るために，細胞を同調培養 し，マルチカラーFISH を用いて各クローンを描出し た。 Igf2/Mpr を含む G 2 とセントロメア側の $119 / 6$ お よびテロメア側の $9 \mathrm{G}$ の 3 クローンを用いて FISH を 行った結果を図 5 に示した。 119/6，G 2 間は約 2-3

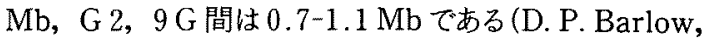




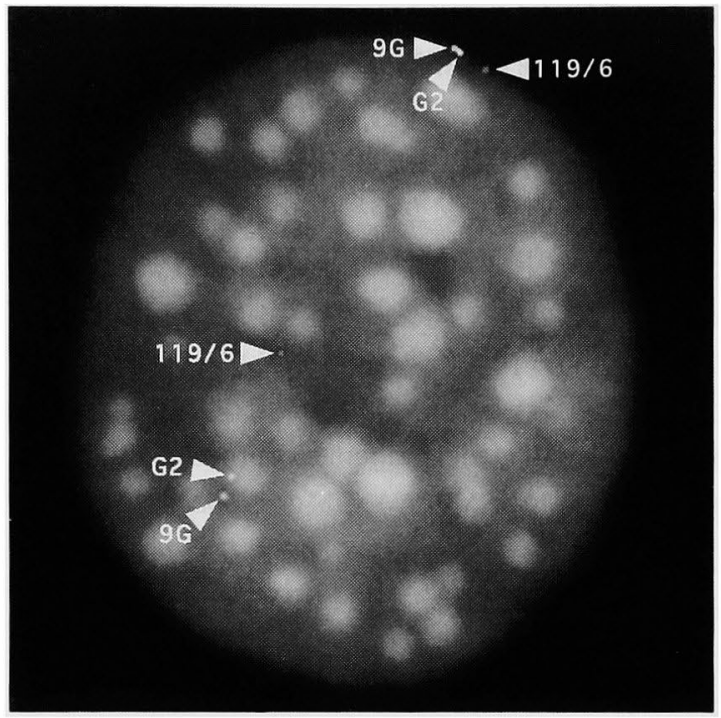

図 5 マウス $\operatorname{Ig} f 2 / M p r$ ドメインのゲノムの伸縮を示す FISH イメージ

一方のアレルがコンパクトな領域を占める.

未発表データ).これは細胞周期の $\mathrm{G}_{1} / \mathrm{S}$ 期の細胞の核 の典型的な FISH イメージである，核を立体的に固定 しているので, このイメージは数枚のフォーカス面の イメージを合成したものであり，実際の距離を直接的 に反映するものではないが，用いた 3 点の間隔がアレ ル間で明らかに異なることがわかる，種々の検討によ り， S 期の早い時期に複製するアレルが伸展状態にあり， 遅い方はコンパクトな領域を占めることを示唆する結 果を得ている.また，このようなアレル間の複製タイ ミングの非同調性, ゲノムの伸縮状態の相違は, ヒス トンの脱アセチル化阻害により消失することを見出し ている(24).これは遺伝子発現に影響を与えるヒストン のアセチル化が染色体ドメインレベルの核内ゲノムの ダイナミックな構造や複製タイミングにも影響するこ とを意味する。

おわりに

本稿では, FISH による動物ゲノムの構造と DNA 複 製の解析例について筆者らの研究を中心に解説した. FISH のゲノム解析計画や生物学への貢献については上 述の通りであるが，さらにその応用性を広げるべく技 術開発が進められている. 例えば，ヒトやマウスの全 染色体を異なる色で見分けるマルチカラーFISH, 検出 感度を上げるための新しい検出系の開発などは, 今後 のこの技術の応用性をますます高めることになろう(28,29).
一方で, 細胞核内でのゲノムの動態に関する研究も FISH を駆使して研究が進められ，三次元解析システムの改 良, RNA, タンパク質の同時検出なども行われている. また,生きた細胞でのゲノムの動態をみる技術も開発, 改良されつつあり,FISH をはじめとする検出系はます ます複雑なメカニズムの検証に活用されることになろ う。筆者は, 動物細胞の核内でゲノムがいかに精妙に 構造変化をし, 遺伝子 (群) の機能を引き出している か, 遺伝子間で如何なる相互作用が可能であるか, ま た，それらは個体レベルでの表現型といかに関連して いるかを明らかにすることを当面の目標としている。 こ のような研究は,極めて基礎的であるにもかかわらず, 多面的な応用性も含んでいる.ゲノムの配列が次々に 決められ，遺伝子の機能を明らかにすることが目標と される現在, 遺伝子のダイナミックな挙動を視覚化し て種々のメカニズムを一つでも多く明らかにしたい.

本研究は, Yale 大学医学部の David C. Ward 教授 の指導のもとに開始し, 三重大学生物資源学部生物化 学研究室において展開したもので, 同教授ならびに, 有益なご助言とご指導を賜りました三重大学名誉教授・ 嶋林幸英先生, 同生物資源学部教授 - 田口 寛先生に 厚く感謝申し上け゚ます。また，共同研究によりご指導 いただいた国立遺伝学研究所教授・池村淑道先生, 東 海大学医学部教授・猪子英俊先生をはじめ, 他研究機 関の諸先生方, ならびに様々な支援を賜りました三重 大学生物資源学部の先生方に心から御礼申し上げます.

最後に，本研究を遂行するにあたって，終始，激励 を賜りました京都大学名誉教授・千葉英雄先生に厚く 御礼申し上げます。

(1) P. Lichter and D. C. Ward : Nature, 345, 93-95 (1990).

（2）松原謙一・吉川 寛（編）：FISH 実験プロトコー ル，秀潤社 (1994).

(3) E. Takahashi, T. Hori, P. O'Connell, M. Leppert and R. White: Hum. Genet., 86, 14-16 (1990).

(4) J. Inazawa, T. Ariyama, T. Tokino, A Tanigami, Y. Nakamura and T. Abe: Cytogenet. Cell Genet., 65, 130-135 (1994).

(5) H-U. G. Weier, M. Wang, J.C. Mullikin, Y. Zhu, J-F. Cheng, K. M. Greulich, A. Bensimon and J. W. Gray: Hum. Mol. Genet., 4, 1903-1910 (1995)

(6) K. Okumura, J. Menninger, R. L. Stallings, N. A. Doggett and D. C. Ward : Cytogenet. Cell 
Genet., 67, 61-67 (1994).

(7) R. L. Stallings, N. A. Doggett, K. Okumura and D. C. Ward : Genomics, 13, 332-338 (1992).

(8) K. Okumura, M. Nogami, H. Taguchi, F. B. Dean, M. Chen, Z.-Q. Pan, J. Hurwitz, A. Shiratori, Y. Murakami, K. Ozawa and T. Eki: Genomics, 25, 274-278 (1995)

(9) H. Akioka, N. E. Forsberg, N. Ishida, K. Okumura, M. Nogami, H. Taguchi, C. Noda and K. Tanaka: Biochem. Biophys. Res. Commn., 207, 318-323 (1995).

(10) K. Okumura, M. Nogami, H. Taguchi, H. Hisamatsu and K. Tanaka : Genomics, 27, 377379 (1995).

(11) A. Shiratori, K. Okumura, M. Nogami, H. Taguchi, T. Inoue, T. Ando, M. Izumi, H. Miyazawa, F. Hanaoka, Y. Murakami and T. Eki: Genomics, 28, 350-353 (1995).

(12) Y. Fujiwara, M. Miwa, K. Okumura, T. Suzuki and M. Ueda: Hum. Genet., in press.

(13) M. Wada, K. Abe, K. Okumura, H. Taguchi, K. Kohno, F. Imamoto, D. Schlessinger and $\mathrm{M}$. Kuwano: Nucleic Acid Res,, 22, 1651-1654 (1994).

(14) H. Kusaba, K. Kohno, K. Asakuno, M. Kuwano, K. Okumura, E. D. Green, D. Schlessinger and M. Wada: Genome Res., 5, 245-258 (1995).

(15) Y. Matsuda, Y-N. Harada, S. NakatsuuneSakai, K. Lee, T. Shiomi and V. M. Chapman : Cytogenet. Cell Genet., 61, 282-285 (1992).

(16) Y. Mukai : Multicolor Fluorescence In Situ Hybridization: A New Tool for Genome Analysis, "Methods of Genome Analysis in Plants",
CRC Press, Boca Raton, p.181-192 (1996).

（17）奥村克純：蛋白質核酸䣲素，37，1546-1554 (1992).

(18) G. P. Holmquist : Am. J. Hum. Genet., 40, 151173 (1987).

(19) S. Selig, K. Okumura, D. C. Ward and H. Cedar：EMBO J., 11，1217-1225，および表紙の 写真 (1992).

(20) G. Bernardi, B. Olofsson, J. Filipski, M. Zerial, J. Salinas, G. Cuny, M. Meunier-Rotival and F. Rodier: Science, 228, 953-958 (1985).

(21) T. Ikemura: Mol. Biol. Evol., 2, 13-34 (1985).

(22) T. Fukagawa, K. Sugaya, K. Matsumoto, K. Okumura, A. Ando, H. Inoko and T. Ikemura : Genomics, 25, 184-191 (1995).

(23) H. Nakamura, T. Morita and C. Sato : Exp. Cell Res., 165, 291-297 (1986).

(24）奥村克純：蛋白質核酸醉素，41，2191-2201 (1996).

（25）奥村克純：組織培養，21，131-134（1995）.

(26) D. Kitsberg, S. Selig, M. Brandeis, I. Simon, I. Keshet, D. J. Driscoll, R. D. Nicholls and H. Cedar: Nature, 364, 459-463 (1993).

(27) M. Nakao and H. Sasaki:J. Biochem., 120, 467-473 (1996)

(28) M. R. Speicher, S. G. Ballard and D. C. Ward: Nature Genet., 12, 368-375 (1996).

(29) E. Schrock, S. du Manoir, T. Veldman, B. Schoell, J. Wienberg, M. A. Ferguson-Smith, Y. Ning, D. H. Ledbetter, I. Bar-Am, D. Soenksen, Y. Garini and T. Ried: Science, 273, 494-497 (1996). 